\title{
Temperature-Dependent Expression of Type III Secretion System Genes and Its Regulation in Bradyrhizobium japonicum
}

\author{
Min Wei, ${ }^{1}$ Keisuke Takeshima, ${ }^{1}$ Tadashi Yokoyama, ${ }^{2}$ Kiwamu Minamisawa, ${ }^{3}$ Hisayuki Mitsui, ${ }^{3}$ \\ Manabu Itakura, ${ }^{3}$ Takakazu Kaneko, ${ }^{4}$ Satoshi Tabata, ${ }^{4}$ Kazuhiko Saeki, ${ }^{5}$ Hirofumi Omori, ${ }^{6}$ \\ Shigeyuki Tajima, ${ }^{7}$ Toshiki Uchiumi, ${ }^{8}$ Mikiko Abe, ${ }^{8}$ Satoshi Ishii, ${ }^{9}$ and Takuji Ohwada ${ }^{1}$ \\ ${ }^{1}$ Department of Food Science, Obihiro University of Agriculture and Veterinary Medicine, Obihiro, Hokkaido 080-8555, Japan; \\ ${ }^{2}$ Tokyo University of Agriculture and Technology, Saiwai-cho, Fuchu 183-8509, Tokyo; ${ }^{3}$ Graduate School of Life Science, \\ Tohoku University, Aoba-ku, Sendai 980-8577, Japan; ${ }^{4}$ Kazusa DNA Research Institute, 2-6-7 Kazusa-Kamatari, Chiba 292- \\ 0812, Japan; ${ }^{5}$ Department of Biological Science, Faculty of Science, Nara Women's University, Kitauoyanishi-machi, Nara 630- \\ 8506, Japan; ${ }^{6}$ Department of Biology, Graduate School of Science, Osaka University, Toyonaka, Osaka 560-0043, Japan; \\ ${ }^{7}$ Department of Life Science, Kagawa University, Miki-cho, Kagawa 761-0795, Japan; ${ }^{8}$ Graduate School of Science and \\ Engineering, Kagoshima University, Kagoshima 890-0065, Japan; ${ }^{9}$ Faculty of Medicine, Oita University, Oita 879-5593, Japan
}

Submitted 22 July 2009. Accepted 14 January 2010.

\begin{abstract}
The genome-wide expression profiles of Bradyrhizobium japonicum in response to soybean (Glycine max (L.) Merr.) seed extract (SSE) and genistein were monitored with time at a low temperature $\left(15^{\circ} \mathrm{C}\right)$. A comparison with the expression profiles of the $B$. japonicum genome previously captured at the common growth temperature $\left(30^{\circ} \mathrm{C}\right)$ revealed that the expression of SSE preferentially induced genomic loci, including a large gene cluster encoding the type III secretion system (T3SS), were considerably delayed at $15^{\circ} \mathrm{C}$, whereas most nodulation (nod) gene loci, including nodD1 and nodW, were rapidly and strongly induced by both SSE and genistein. Induction of the T3SS genes was progressively activated upon the elevation of temperature to $30^{\circ} \mathrm{C}$ and positively responded to culture population density. In addition, genes nolA and nodD2 were dramatically induced by SSE, concomitantly with the expression of T3SS genes. However, the deletion mutation of nodD2 but not nolA led to elimination of the T3SS genes expression. These results indicate that the expression of the T3SS gene cluster is tightly regulated with integration of environmental cues such as temperature and that NodD2 may be involved in its efficient induction in $B$. japonicum.
\end{abstract}

The (Brady)rhizobium-legume symbiotic interaction is an extremely elaborate process controlled by the exchange of molecular signals between two partners. The early event of this interaction involves the triggering of the nodule development by the lipo-chitin oligosaccharide (Nod factors), which are synthesized by the products of bacterial nodulation (nod, noe, and $n o l$ ) genes in response to host plant-released flavonoids (Kosslak et al. 1987; Schultze and Kondorosi 1998). Bradyrhizobium japonicum is a nitrogen-fixing endosymbiont associated with soybean (Glycine max). The accumulating evidence sug-

Corresponding author: T. Ohwada; Telephone: +81-155-49-5552; Fax: +81-155-49-5577; E-mail: taku@obihiro.ac.jp

* The $\boldsymbol{e}$-Xtra logo stands for "electronic extra" and indicates that five supplementary tables and two supplementary figures are available online and that Figures 1, 2, 4, and 6 appear in color online. gests that the relationship between soybean-released isoflavones (i.e., genistein and daidzein) and B. japonicum-produced Nod factors is important but does not fully explain the signal interactions that occur during the early stage of symbiosis (Becker et al. 1998; Broughton et al. 2000; Krause et al. 2002). Genistein has recently been reported to possess a much broader function than mere induction of nod genes (Lang et al. 2008). A recent study also demonstrated that, compared with genistein, soybean seed extracts (SSE) remarkably and preferentially express many genomic loci such as those encoding the type III secretion system (T3SS), polygalacturonase inside the symbiosis island as well as exopolysaccharide (EPS) synthesis, ribosomal protein family, and 1-aminocyclopropane-1-carboxylate (ACC) deaminase outside the symbiosis island in B. japonicum (Wei et al. 2008).

The symbiotic association between Rhizobium spp. and leguminous plants is strongly affected by suboptimal environmental conditions such as salinity, unfavorable soil $\mathrm{pH}$, nutrient deficiency, mineral toxicity, desiccation, and temperature extremes (Zahrm 1999). The optimal B. japonicum-soybean symbiosis requires root zone temperatures (RZT) ranging from 25 to $30^{\circ} \mathrm{C}$ (Jones and Tisdale 1921; Dart and Day 1971). Studies involving B. japonicum are usually carried out under laboratory rather than field conditions, typically with a growth temperature of $28^{\circ} \mathrm{C}$, at which this bacterium is considered to grow best. In fact, soil temperature in short-season soybean production areas is often below this range and the bacterium has to adapt and continue to grow under this suboptimal temperature condition. Suboptimal RZT, particularly that lower than $17.5^{\circ} \mathrm{C}$, was reported to strongly inhibit the process of nodulation and nitrogen fixation due to the delayed initiation of infection threads and nodule development, and the decreased biosynthesis and secretion of genistein (Lynch and Smith 1993; Zhang and Smith 1994, 1996). Application of genistein to inocula and soil could overcome the low-temperature inhibition of soybean nodulation and nitrogen fixation (Zhang and Smith 1997; Belkheir et al. 2000; Leibovitch et al. 2001). However, these reports focused mainly on investigating the nodule mass, various morphological changes (i.e., root-hair curling and infection thread), Nod factors production, and selection of low temperature-tolerant strains. Little is known 
about the molecular basis of B. japonicum-soybean interaction at low temperature.

In this study, the global expression profiles of B. japonicum in response to SSE and genistein were monitored with time at $15^{\circ} \mathrm{C}$ and compared with the results of a previous study at $30^{\circ} \mathrm{C}$ (Wei et al. 2008). The results revealed that the T3SS gene cluster showed a potential expression lag and was progressively activated with the increase in temperature, whereas the nodulation gene loci were readily induced at $15^{\circ} \mathrm{C}$. The $B$. japonicum T3SS gene cluster was proposed to be induced by genistein through a regulatory cascade involving components NodD1 and NodW (Krause et al. 2002). However, compared with genistein, SSE remarkably and collectively induced the T3SS gene cluster at both 30 and $15^{\circ} \mathrm{C}$, indicating that SSE is essential for its full induction and is important in the elucidation of the regulatory mechanism of T3SS in B. japonicum. Consequently, the comparative genome-wide expression profiles between SSE- and genistein-treated cells led to the finding that the efficient induction of the T3SS genes was accompanied by that of both the nolA and nodD2 genes. Further expression analyses using mutants provided experimental evidence that NodD2 but not NolA may be involved in the efficient induction of the B. japonicum T3SS gene cluster.

\section{RESULTS}

\section{Nodulation gene loci are rapidly and strongly induced at low temperature.}

To compare the genome-wide expression profiles of $B$. japonicum in response to SSE $(20 \mu \mathrm{l} / \mathrm{ml}$ culture $)$ and genistein $(5$ $\mu \mathrm{M})$ with those at $30^{\circ} \mathrm{C}$, the induction periods were determined using nod $Y$ expression by a nodY-lacZ transcriptional fusion at $15^{\circ} \mathrm{C}$. The result showed that nodY expression increased with time and reached a maximum at $20 \mathrm{~h}$ postinduction (hpi) for both SSE- and genistein-treated cells, and their expression patterns were also similar (Supplementary Fig. S1). Based on this result, 12 and 20 hpi were used for the macroarray analyses in this experiment because the nod $Y$ expression reached a maximum at $30^{\circ} \mathrm{C}, 12 \mathrm{hpi}$. Three time points $(0.5,6$, and 12 hpi) during the elevation phase were chosen for the global expression analyses (Wei et al. 2008). A longer induction period up to $48 \mathrm{hpi}$ was also chosen for RNA isolation for reasons which will be explained below.

The genome-scale expression profiles of B. japonicum in response to $\mathrm{SSE}$ and genistein at 12 and $20 \mathrm{hpi}$ at $15^{\circ} \mathrm{C}$ were constructed with the value of $\log _{10}$ (expression ratio) of each clone (a total of 3,960 overlapping clones which covered $98.5 \%$ of the whole genome), representing the relative expression levels of clones between the SSE- or genistein-treated and untreated cells (Fig. 1). SSE induced the symbiosis island of $B$. japonicum as four predominant expression clusters (EC-I to EC-IV) at $30^{\circ} \mathrm{C}, 12 \mathrm{hpi}$ (Wei et al. 2008). However, only three distinguishably expressed loci were detected at both 12 and 20 hpi at $15^{\circ} \mathrm{C}$, with two of them being a part of EC-I and EC-II and another corresponding well with EC-IV. Unexpectedly, EC-III was completely invisible. Such expression portraits of the symbiosis island were very similar, not only between the SSE- and genistein-treated cells but also with those previously captured at $30^{\circ} \mathrm{C}, 6 \mathrm{hpi}$.

The three distinguishably expressed genomic loci involved most of the known nodulation genes (Fig. 2; Supplementary Table S1); that is, five genes-blr1629, bll1630(nolK), bll1631(noeL), blr1632(nodM), and blr1633(noeD)—in ECI; four genes-bsl1713, bll1714(nodW), bll1715(nodV), and blr1716-in EC-II; a common nod gene operon, nolZY-nolAnodD2-nodD1YABCSUIJ-nolMNO-nodZ(bsl2014-blr2035); and three genes-bsr2061, blr2062 (noeI), and bll2063( $n r g C)$-in EC-IV. A comparison of the expression levels of these nodulation loci with those at $30^{\circ} \mathrm{C}$ showed that the clones covering blr1629, bll1630(nolK), bll1631(noeL), blr1632(nodM), and blr1633(noeD), and bsll713, bll1714(nodW), bll1715(nodV), and blr1716, as well as bsr2061 and blr2062(noeI) were significantly induced at $15^{\circ} \mathrm{C}, 12 \mathrm{hpi}$, even higher than at $30^{\circ} \mathrm{C}, 6 \mathrm{hpi}$, for both the SSE and genistein treatments. However, their induction dropped to a very low level at 48 hpi. Clone 20 (in EC-IV)—covering bsr2061 and blr2062(noel)—was the most strongly induced clone on the whole genome of SSE- and genistein-induced cells at 12 hpi (173- and 200-fold) and $20 \mathrm{hpi} \mathrm{(101-} \mathrm{and} \mathrm{82-}$ fold), suggesting that noeI likely plays an important role in the early stage of B. japonicum-soybean symbiosis at a low temperature. These results indicate that the nod genes are strongly induced in the early stage at a low temperature and a part of nod genes involving in the modification of Nod factors was even induced at a higher level than at $30^{\circ} \mathrm{C}$.

The expression of clones covering the nod gene loci mentioned above showed a generally decreasing tendency from 6 to $12 \mathrm{hpi}$ at $30^{\circ} \mathrm{C}$ and 12 to $48 \mathrm{hpi}$ at $15^{\circ} \mathrm{C}$. However, a different trend was exhibited for three clones in EC-IV, clone 2 covering genes from bsl2014 to bll2016 and clones 3 and 4 from bll2017 to bll2023. The expression of clone 2, covering genes bsl2014, bsl2015(nolZ), and bll2016(nolY), increased with time in both SSE- and genistein-treated cells, whereas those of clones 3 and 4 increased in only the SSE-treated cells from 6 to $12 \mathrm{hpi}$ at $30^{\circ} \mathrm{C}$ and 20 to $48 \mathrm{hpi}$ at $15^{\circ} \mathrm{C}$. Interestingly, a bll2023(nodD1), bll2021(nodD2), and bll2019(nolA) gene region was found to be covered by the two overlapping clones 3 and 4. In B. japonicum, NodD1 responds to genistein and functions as a positive transcriptional activator of the common nodABCSUIJ operon, whereas NolA and NodD2 form two key components in the feedback regulation as well as quorum regulation of the nodulation genes (Loh and Stacey 2003). The unusual expression patterns of these two overlapping clones imply that this nodD1nodD2nolA gene region may be involved in the regulation of some SSE preferentially induced genome loci.

\section{Expression of T3SS gene cluster \\ is positively temperature dependent.}

Because EC-III covers a large T3SS gene cluster (Wei et al. 2008), its invisibility at both 12 and $20 \mathrm{hpi}$ at $15^{\circ} \mathrm{C}$ led to the hypothesis that the expression of the T3SS gene cluster is temperature dependent. Therefore, the expression of the T3SS gene cluster in SSE- and genistein-treated cells was examined at various temperatures $\left(20,25\right.$, and $\left.30^{\circ} \mathrm{C}\right)$ and at $15^{\circ} \mathrm{C}$ for longer periods $(36,48$, and $72 \mathrm{~h})$ using three representative T3SS genes, bll1843, blr1816, and blr1649, which encode a transcriptional activator (TtsI), a core structural (RhcN), and an unknown secreted protein, respectively (Krause et al. 2002; Süß et al. 2006).

In the presence of SSE, the expression of all these genes tended to increase as the temperatures elevated from 15 to $30^{\circ} \mathrm{C}$ (Fig. 3A). For example, although showing no substantial expression at $15^{\circ} \mathrm{C}, 12 \mathrm{hpi}$, they were induced somewhat and significantly at the same induction periods at 20 and $30^{\circ} \mathrm{C}$, suggesting that their expression lag tended to be shortened as the temperature increased. Interestingly, their induction showed an increasing tendency with time at a certain temperature, suggesting that the expression of T3SS genes is most likely cellgrowth-phase-dependent because the sufficient growth of cells occurred with the addition of SSE but not genistein. In contrast, this temperature-dependent expression manner was not observed in the genistein-treated cells. Although ttsI was strongly induced at $20^{\circ} \mathrm{C}, 12 \mathrm{~h}$, and maintained a higher level at the same 
induction periods at 25 and $30^{\circ} \mathrm{C}$, the expression levels of the other two genes ( $r h c N$ and blr1649) were not substantially altered. To determine whether they have a longer expression lag at $15^{\circ} \mathrm{C}$, the induction periods were extended up to $72 \mathrm{hpi}$. The results showed that the expression of all three genes increased with time and reached a maximum at $48 \mathrm{hpi}$ in the presence of SSE (Fig. 3B). On the other hand, ttsI started to be strongly in- duced by genistein at 20 hpi but the expression of both blr1649 and $r h c N$ was not substantially changed until 72 hpi after the induction at 36 hpi. These results supported the hypothesis that the induction of the T3SS genes was temperature dependent in the presence of SSE but not genistein.

Subsequently, the cells were induced with SSE and genistein for up to $48 \mathrm{~h}$ at $15^{\circ} \mathrm{C}$ for the construction of genome-wide
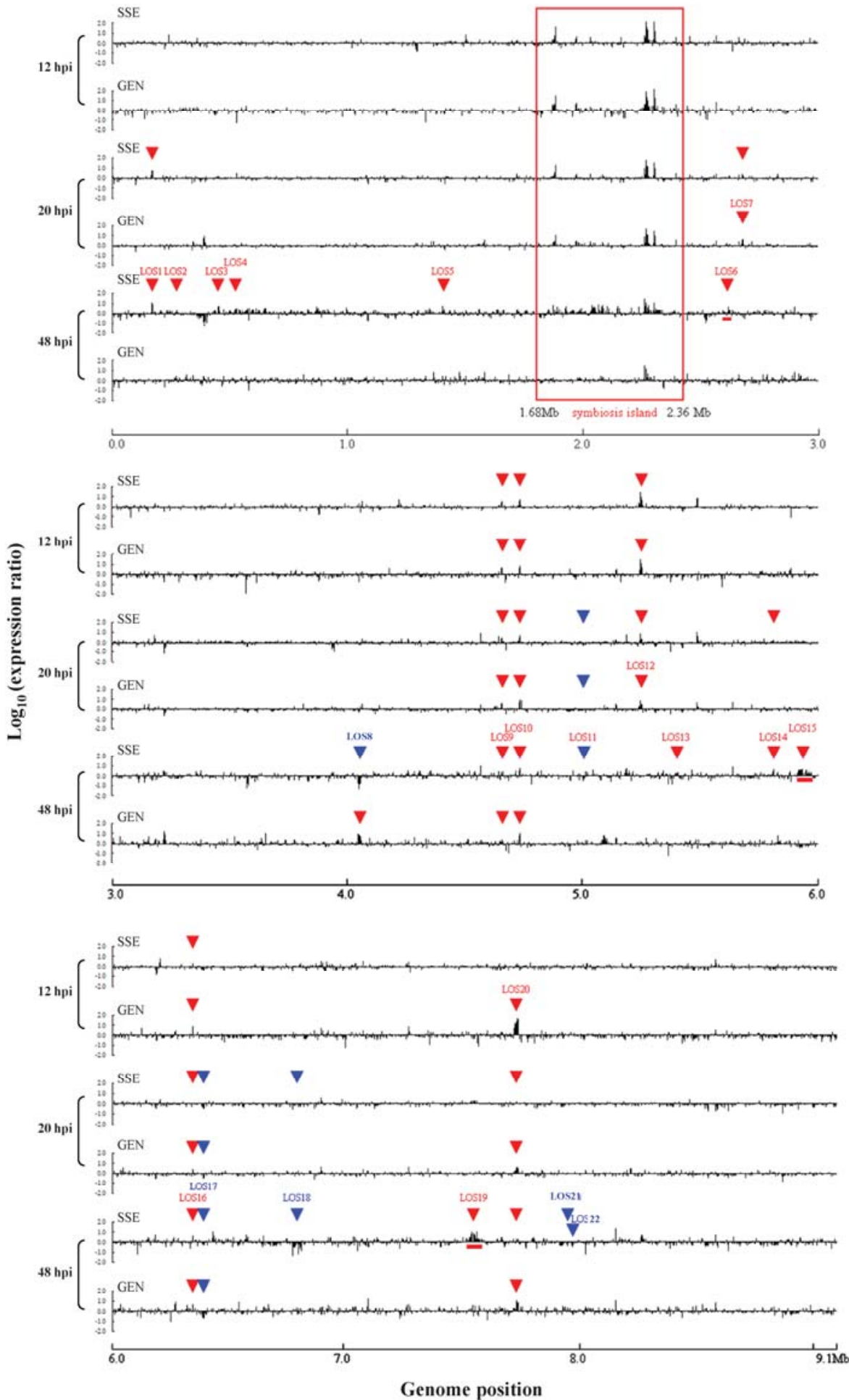

Fig. 1. Genome-wide expression profiling of Bradyrhizobium japonicum USDA 110 in response to soybean seed extract (SSE) and genistein (GEN) at 12 , 20 , and $48 \mathrm{~h}$ postinduction (hpi) at $15^{\circ} \mathrm{C}$. Expression profiles were constructed with the value of $\log _{10}$ (expression ratio) of each clone (a total of 3,960 overlapped M13 clones covering the whole genome), which represent the relative expression levels of clones between SSE- or GEN-treated and untreated cells. Expression levels of each clone represent the mean of at least two replicates and are sorted according to their genome coordinate. The symbiosis island is located on the chromosome at coordinate 1.68 to $2.36 \mathrm{Mb}$ (Kaneko et al. 2002). Red and blue arrowheads indicate positions of some strongly induced and reduced loci outside the symbiosis island (LOS) (LOS1 to LOS22), respectively. 
expression profiles by using macroarrays (Fig. 1). SSE expressed the symbiosis island with a similar profiling to that at $30^{\circ} \mathrm{C}, 12 \mathrm{~h}$, and EC-III also emerged (Fig. 2), although the expression levels of clones covering the T3SS gene cluster were generally weaker than those at $30^{\circ} \mathrm{C}$. Conversely, some of these clones showed somewhat of an expression response to genistein but only four clones (clones 16, 18, 19, and 28) still showed an expression level above 2.2-fold, a cut-off for clones

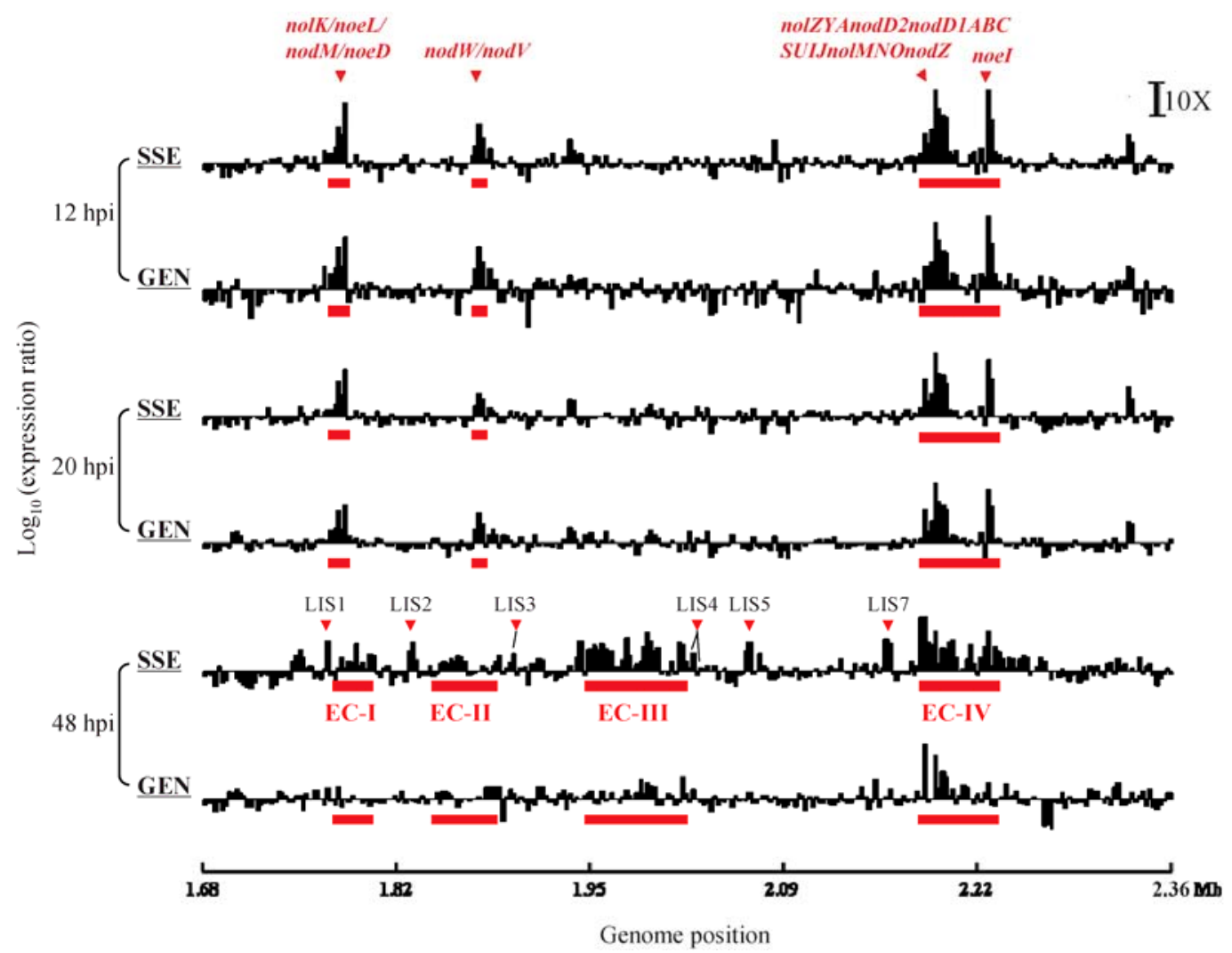

Fig. 2. Expression profiles of the symbiosis island of Bradyrhizobium japonicum USDA 110 induced by soybean seed extract (SSE) and genistein (GEN) at 12,20 , and $48 \mathrm{~h}$ postinduction (hpi) at $15^{\circ} \mathrm{C}$. Expression profiles were constructed as the value of $\log _{10}$ (expression ratio) of 276 clones covering symbiosis island. Expression clusters (EC-I to EC-IV) indicate four predominant expression clusters, and LIS (LIS1 to LIS5 and LIS7) represent loci inside the symbiosis island but outside EC preferentially induced by SSE at $12 \mathrm{hpi}$ at $30^{\circ} \mathrm{C}$ (Wei et al. 2008).

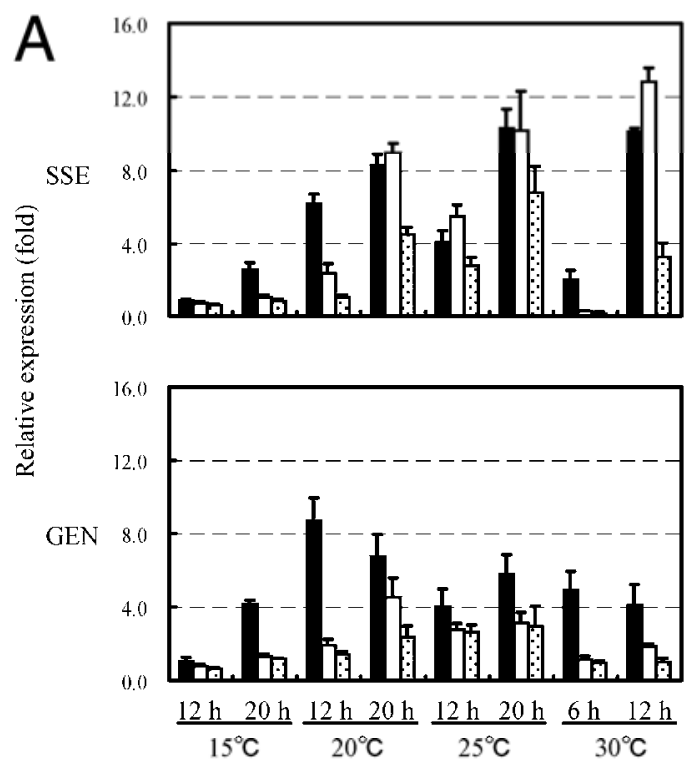

Induction periods at various temperatures
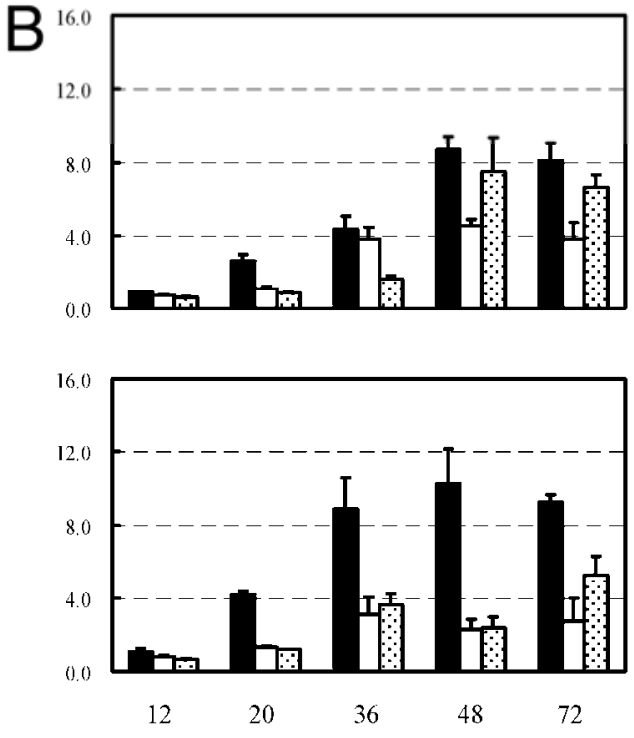

Induction periods at $15^{\circ} \mathrm{C}$ (hours)

attsI $\square$ rhcN @blr1649

Fig. 3. Expression patterns of Bradyrhizobium japonicum type III secretion system (TTSS) genes at A, various temperatures and B, various induction periods at $15^{\circ} \mathrm{C}$ in the presence of soybean seed extract (SSE) or genistein (GEN). Three representative TTSS genes $(t t s I, r h c N$, and $b l r 1649)$ were used and the relative expression levels were quantified in normalization of gene sigA by using real time reverse-transcriptase polymerase chain reaction. 
with a statistically significant expression (Wei et al. 2008). Gene ttsI, which has been reported to be essential for the expression of other genes in the T3SS gene cluster in the presence of genistein (Krause et al. 2002), was covered by clone 19. Other SSE exclusively induced clones within EC at $30^{\circ} \mathrm{C}, 12 \mathrm{~h}$, were also detected at $15^{\circ} \mathrm{C}, 48 \mathrm{~h}$; that is, clone 7 (in EC-I) covering gene bsl1639, clones 11 and 12 covering genes from blr1649 to bsl1654, and clones 9 and 10 (in ECII) covering genes blr1704 and blr1705. Although the products of these genes are still unknown, they are suggested to be likely T3SS related (Zehner et al. 2008). These results demonstrate that low temperature leads to a potentially delayed expression of the T3SS gene cluster and SSE is essential for its full induction even at low temperature.

\section{Both nodD2 and nolA are strongly co-induced with T3SS genes.}

The expression of clones covering the nod genes showed a generally decreasing tendency with time for SSE and genistein treatments. This is reasonable because the expression of both nod $W$ and nodD1, which have been proposed to encode two positive transcriptional activators of nod genes (Loh and Stacey 2003), declined with time (Table 1). In contrast, the expression of the two overlapped clones 3 and 4 within EC-IV, which involve an important regulatory genome region (nodD1nodD2nolA), increased with time in SSE-treated cells at both 30 and $15^{\circ} \mathrm{C}$ (Fig. 4). The expression of gene nodD1, which was individually polymerase chain reaction (PCR) amplified and regularly spotted as control clones on the array membrane, de-

Table 1. Expression pattern of regulatory genes related to the nodulation and type III secretion system in response to soybean seed extract (SSE) and genistein $(\mathrm{GEN})$ at 30 and $15^{\circ} \mathrm{C}^{\mathrm{a}}$

\begin{tabular}{|c|c|c|c|c|c|c|c|c|}
\hline Inducer & $\begin{array}{l}\text { Induction } \\
\text { conditions }\end{array}$ & nodW & $\operatorname{nodDI}^{\mathrm{b}}$ & nodD2 & nolA & tts I & $\begin{array}{c}\text { Expression profiling } \\
\text { of EC-III }\end{array}$ & Reference $^{\mathrm{c}}$ \\
\hline SSE & $30^{\circ} \mathrm{C}, 6 \mathrm{~h}$ & $2.3 \pm 0.2$ & $5.6 \pm 0.9$ & $3.8 \pm 0.9$ & $3.2 \pm 0.3$ & $2.1 \pm 0.5$ & Undetectable & Wei et al. 2008 \\
\hline GEN & & $3.2 \pm 0.5$ & $5.5 \pm 0.6$ & $4.1 \pm 1.3$ & $2.7 \pm 0.2$ & $4.9 \pm 1.0$ & Undetectable & $\ldots$ \\
\hline SSE & $30^{\circ} \mathrm{C}, 12 \mathrm{~h}$ & $1.8 \pm 0.3$ & $3.8 \pm 1.0$ & $26.1 \pm 3.2$ & $8.0 \pm 1.5$ & $10.1 \pm 0.2$ & Fully and strongly & $\ldots$ \\
\hline GEN & & $2.9 \pm 0.3$ & $2.2 \pm 0.4$ & $2.4 \pm 0.9$ & $1.5 \pm 0.4$ & $4.1 \pm 1.1$ & Partially and weakly & \\
\hline SSE & $15^{\circ} \mathrm{C}, 20 \mathrm{~h}$ & $2.1 \pm 0.5$ & $4.2 \pm 0.5$ & $3.0 \pm 0.8$ & $3.1 \pm 0.5$ & $2.6 \pm 0.4$ & Undetectable & This study \\
\hline GEN & $\ldots$ & $4.9 \pm 0.6$ & $4.1 \pm 0.4$ & $2.5 \pm 0.1$ & $2.6 \pm 0.5$ & $4.2 \pm 0.2$ & Undetectable & $\ldots$ \\
\hline SSE & $15^{\circ} \mathrm{C}, 48 \mathrm{~h}$ & $0.6 \pm 0.0$ & $2.5 \pm 0.3$ & $5.8 \pm 0.7$ & $7.6 \pm 1.9$ & $8.0 \pm 1.5$ & Fully and strongly & $\ldots$ \\
\hline GEN & $\ldots$ & $1.0 \pm 0.3$ & $1.1 \pm 0.3$ & $2.4 \pm 0.3$ & $2.2 \pm 0.3$ & $5.3 \pm 1.4$ & partially and weakly & $\ldots$ \\
\hline
\end{tabular}

${ }^{a}$ Relative expression levels are quantified by using real-time reverse-transcriptase polymerase chain reaction (PCR) on the normalization of those of sigA, a housekeeping gene of $B$. japonicum and represent the mean of three replicates.

${ }^{\mathrm{b}}$ Relative expression level from array analyses with PCR-amplified fragments (at the coordinate 2,182,483 to 2,183,285), which were dotted as control spot on the membrane.

${ }^{\mathrm{c}}$ Expression profiling of EC-III shown in the figures in the references.

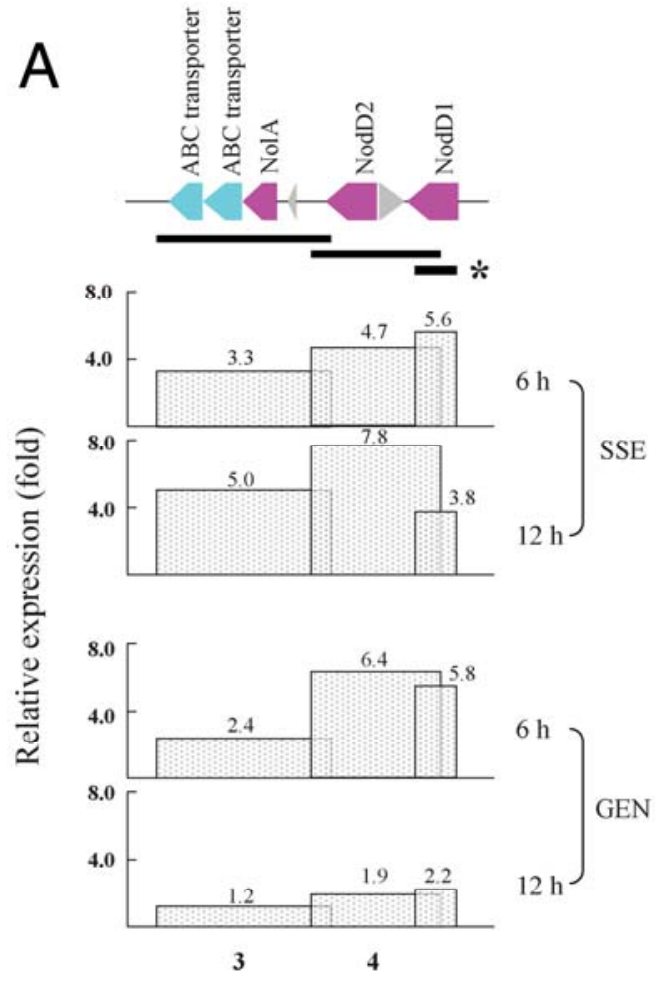

Clone No. in EC-IV
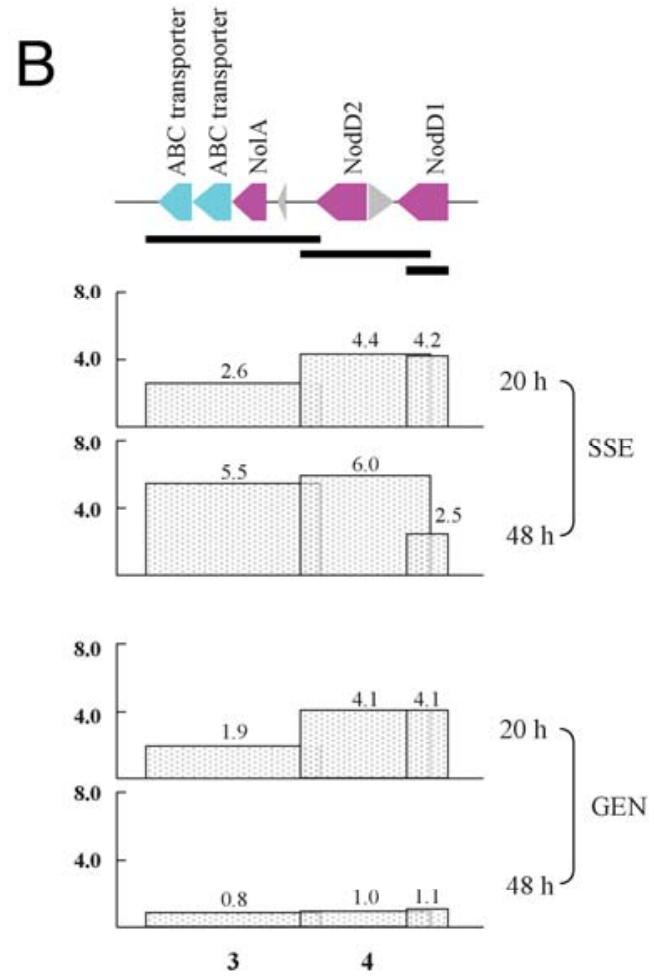

Clone No. in EC-IV

Fig. 4. Differential expression of two adjacent clones, clones 3 (brb17558, at the coordinate 2,177,445 to 2,180,846) and 4 (brb00631, at the coordinate 2,180,444 to 2,182,985), which cover a nodD1nodD2nolA gene region, in the presence of soybean seed extract (SSE) and genistein (GEN) with time at A, $30^{\circ} \mathrm{C}$ and $\mathbf{B}, 15^{\circ} \mathrm{C}$. Bars below the gene map indicate $\mathrm{M} 13$ clone inserts for macroarray construction and the box charts below them indicate the relative expression levels of M13 clones in SSE- or GEN-treated Bradyrhizobium japonicum USDA 110 cells to untreated cells. Clones with a star indicate polymerase chain reaction-amplified nodDl fragment, which is spotted regularly on the array membrane. Genes encoding unknown or hypothetical proteins are colored gray. Each datum represents the mean of at least two independent experiments and each experiment was done in duplicate array membranes. 
creased with time in both SSE- and genistein-treated cells, and a significantly different expression between nodD1 and clone 4 was found only in SSE-treated cells at $30^{\circ} \mathrm{C}, 12 \mathrm{hpi}$ and at $15^{\circ} \mathrm{C}, 48 \mathrm{hpi}$. These results suggest that both or either nodD2 and nolA are strongly and exclusively induced by SSE because nolA was covered by only clone 3 and nodD2 by both.

nodD2 and nolA were strongly and exclusively induced by SSE at both $30^{\circ} \mathrm{C}, 12 \mathrm{hpi}$ and $15^{\circ} \mathrm{C}, 48 \mathrm{hpi}$ (Table 1). A significantly higher induction (26.1-fold) was observed for nodD2 at $30^{\circ} \mathrm{C}, 12$ hpi compared with that at $15^{\circ} \mathrm{C}, 48 \mathrm{hpi}$, whereas those of nolA did not seem to be substantially influenced by the low temperature. A significant induction of ttsI was observed in SSE-treated cells at both $30^{\circ} \mathrm{C}, 12 \mathrm{hpi}$ (10.1-fold) and $15^{\circ} \mathrm{C}, 48$ hpi (8.0-fold). Because the expression of nodW and nodD1 was significantly decreased under the same conditions, these results suggest that the induction of ttsI may accompany that of nodD2 and nolA. The induction of ttsI was also observed in genisteintreated cells but seemed not to be substantially altered during the induction at either 30 or $15^{\circ} \mathrm{C}$, ranging from 4.1 - to 5.3 -fold. However, genes nodW and nodDl were induced by genistein at a higher level at both $30^{\circ} \mathrm{C}, 6 \mathrm{hpi}$ and $15^{\circ} \mathrm{C}, 20$ (even 12) hpi, suggesting that induction of the T3SS gene cluster cannot be simply explained by the paradigm of the NodD1/NodW-regulatory pathway proposed by Krause and associates (2002).

\section{Induction of T3SS genes positively responds to culture population density.}

It was reported that the significant repression of nod genes of B. japonicum at a high cell population density occurred via the NolA-NodD2-mediated quorum control (Loh and Stacey 2003). Besides the possibility of NodD2/NolA involvement in the induction of T3SS genes as mentioned above, SSE significantly stimulated the growth of $B$. japonicum cells at both 30 and $15^{\circ} \mathrm{C}$, especially the former, compared with genistein (Supplementary Fig. S2). Furthermore, the expression of three representative T3SS genes increased with time at a certain temperature in the presence of SSE (Fig. 3A). These results suggest that the expression of T3SS genes is likely cellgrowth-phase-dependent, with the positive regulation via the NolA-NodD2-mediated quorum.

Although the supernatant from arabinose-gluconate (AG) and defined minimal medium were addressed to suppress nod genes expression in a cell-density-dependent manner (Loh et al. 2001; Jitacksorn and Sadowsky 2008), there has been no report on yeast extract-mannitol broth (YMB) medium used in this study. Thus, the effect of cell-density-dependent factors (conditioned medium $[\mathrm{CM}]$ and cell density factor $[\mathrm{CDF}]$ ) (described below) from YMB culture with high population density on the induction of nodY-lacZ in B. japonicum by SSE and genistein was investigated first. The addition of CM and CDF to B. japonicum culture with various initial population densities (optical density at $600 \mathrm{~nm}\left[\mathrm{OD}_{600}\right]=0.1,0.05$, and 0.025 ) resulted in the repression of nodY induction by SSE and genistein (data not shown), suggesting that supernatants from YMB culture with a high population density also contain a quorum-sensing factor that represses the expression of nod genes. Subsequently, the effect of CM and CDF on the expression of T3SS genes in the presence of genistein, which is considered to play a role in triggering the T3SS genes induction through NodD1 and NodW (Krause et al. 2002), was examined. The addition of $\mathrm{CM}$ or CDF to the B. japonicum culture resulted in the enhanced induction of ttsI and $r h c N$ but not blr1649 (Fig. 5A). It is likely that, in the presence of genistein, the induction of genes encoding conserved T3SS regulatory activator and core structures but not diverse secreted proteins positively respond to culture population density.

\section{Deletion of a DNA fragment carrying nodD2, not nolA, results in the elimination of $\mathrm{T} 3 \mathrm{SS}$ expression.}

To elucidate whether nodD2 or nolA are involved in the regulation of T3SS induction, the expression of T3SS genes (ttsI, rhcN, and blr1649) in strains $\Delta 370$ (nodD2 deletion) and $\mathrm{BjB} 3$ (nolA deletion) in response to $\mathrm{SSE}$ at $30^{\circ} \mathrm{C}, 12 \mathrm{hpi}$ and $15^{\circ} \mathrm{C}, 48$ hpi were examined. No substantial expression response of nodD2 and nolA in these mutants to SSE confirmed the stable mutagenesis of these two genes (data not shown). The induction of these T3SS-related genes, particularly $t t s I$ and $r h c N$, was undetectable in strain $\Delta 370$, although stronger induction of them was observed in strain BjB3 compared with the wild type (Fig. 5B). In addition, the expression of these three T3SS-related genes was also examined by the addition of $\mathrm{CM}$ or $\mathrm{CDF}$ to the culture of strain $\triangle 370$ in the presence of genistein at $12 \mathrm{hpi}$ at $30^{\circ} \mathrm{C}$. Unexpectedly, the induction of genes $t t s I$ and $r h c N$ were also completely
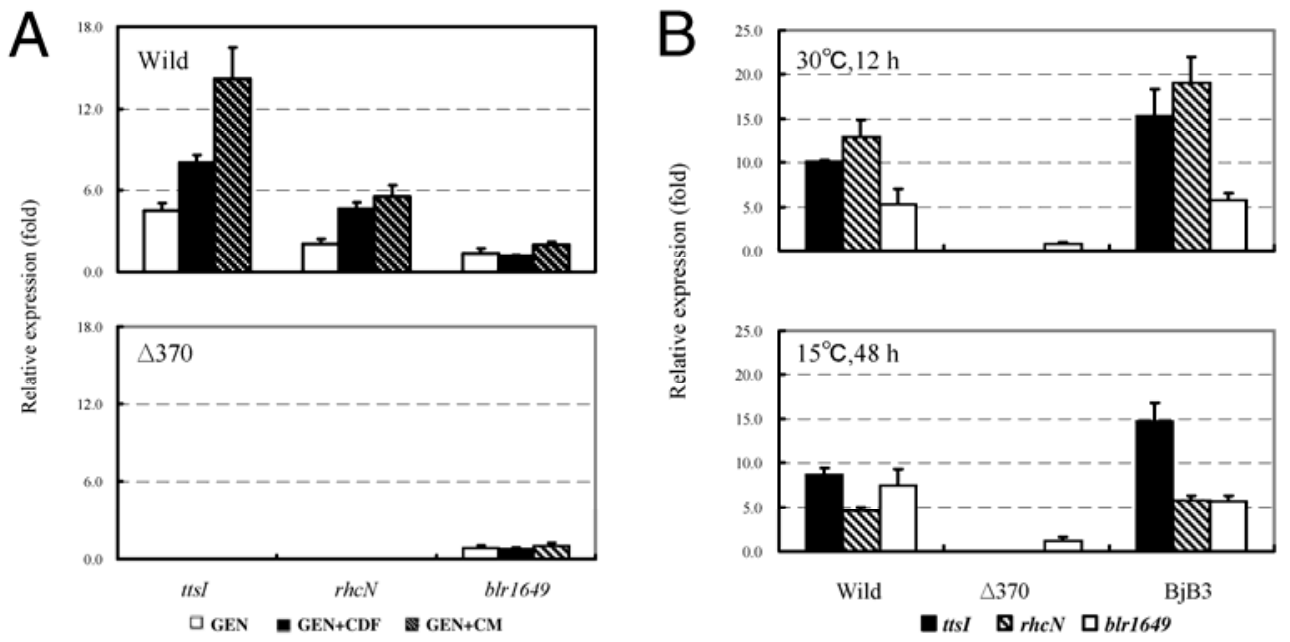

Fig. 5. A, Effect of cell-density-dependent factor on the induction of three representative type III secretion system (TTSS) genes (ttsI, rhcN, and blr1649) in the wild type (Bradyrhizobium japonicum USDA 110) and nodD2-deleted mutant $\Delta 370$ in the presence of genistein $(5 \mu \mathrm{M})$ at $30^{\circ} \mathrm{C}$ for $12 \mathrm{~h}$. Conditioned medium $(\mathrm{CM})$ and cell density factor $(\mathrm{CDF}$ ) (ethyl acetate-extracted $\mathrm{CM}$ ) were prepared from B. japonicum culture (optical density at $600 \mathrm{~nm}=$ approximately 1.6 to 1.8 ) and added to the culture. B, Expression profiles of these three representative TTSS genes in wild-type, $\triangle 370$, and BjB3 cells upon exposure of soybean seed extract at $30^{\circ} \mathrm{C}, 12 \mathrm{~h}$ postinduction (hpi) and $15^{\circ} \mathrm{C}, 48 \mathrm{hpi}$. Expression levels were normalized on the housekeeping gene of $B$. japonicum, sigA, and represented the mean of three replicates. 
undetectable (Fig. 5A). Instead, a macroarray platform was used to get a view of the expression profile of the symbiosis island in these two SSE-treated mutants at $30^{\circ} \mathrm{C}, 12 \mathrm{hpi}$ and $15^{\circ} \mathrm{C}, 48 \mathrm{hpi}$. EC-III was not detected in $\Delta 370$ but in $\mathrm{BjB} 3$, whereas EC-IV was observed in both (Fig. 6; Supplementary Table S5). These results suggested that NodD2 is likely involved in the full induction of T3SS genes in SSE-treated $B$. japonicum USDA 110 cells.

\section{DISCUSSION}

In this study, nod gene loci were induced rapidly and strongly at $15^{\circ} \mathrm{C}$, and part of them even showed a higher expression level than at $30^{\circ} \mathrm{C}$. It has been reported that the amount of Nod factor of $B$. japonicum USDA 110 was markedly decreased at low temperatures $\left(15\right.$ and $17^{\circ} \mathrm{C}$ ) (Zhang et al. 2002; Duzan et al. 2006) but there are no reports on its structural modification upon exposure to the low temperature. Rhizobium leguminosarum was reported to produce relatively larger amounts of nodX-mediated, acetylated lipo-chitooligosaccharides (LCO) at 12 than at $28^{\circ} \mathrm{C}$ (Olsthoorn et al. 2000). The product of noeI was suggested to be probably involved in the modification of the Nod factor of $B$. japonicum with its 2-O-methylation of the fucosyl group (Göttfert et al. 2001). Therefore, the results obtained here not only strongly support the established knowledge that the products of the nod gene loci are the essential determinant for triggering early plant responses such as root hair curling and induction of meristem formation but also suggest that a modified structure of LCO of $B$. japonicum mediated by part of nod genes such as noeI is likely activated at low temperature.

On the other hand, other SSE preferentially induced genomic loci such as those encoding polygalacturonase (blr1993 in LIS7), ACC deaminase (LOS2), energy metabolism (ATP synthase in LOS4 and LOS5, NADH ubiquinone oxidoreductase in LOS13), EPS synthesis (LOS6), and the ribosome protein family (LOS15) also showed potentially delayed expression at low temperature (Figs. 1 and 2; Supplementary Tables S2 and $\mathrm{S} 3$ ). These genome components are simultaneously induced with T3SS, suggesting that T3SS may play a pivotal role in the integrated regulation circuits in B. japonicum for the development of symbiosis. Recently, many virulence determinants in Ralstonia solanacearum such as wall-degrading enzymes and EPS have been reported to be regulated in concert with T3SS (Valls et al. 2006). In addition, the results here suggest that the delayed expression of these genome components may be responsible for the delay in nodule development of soybean at low RZT. Taking into consideration that B. japonicum T3SS genes were induced early in the development to bacteroid (i.e., maximally induced in the bacteroid 10 and 13 days postinoculation) (Pessi et al. 2007), it is likely that the early infection stages (e.g., infection thread elongation, release into plant cells, and bacterial differentiation into mature bacteroids) is most sensitive to low temperature and, perhaps, to other environmental stresses such as salinity, unfavorable soil $\mathrm{pH}$, nutrient deficiency, and mineral toxicity. It was also demonstrated that the expression lag of all three representative T3SS genes was progressively extended upon the drop in temperature. This provides a molecular explanation for the previous report that, when the RZT dropped from 25 to $17.5^{\circ} \mathrm{C}$, infection initiation of soybean was delayed 1 day, while a further decrease from 17.5 to $15^{\circ} \mathrm{C}$ delayed infection initiation for another 2 days (Zhang and Smith 1994), which suggested that decrease of temperature inhibited the initial interaction of B. japonicumsoybean in a progressive manner by the expression retardation of T3SS genes. Therefore, these results suggest that, if the expression lag of T3SS is reduced at low temperature, the development of nodules in soybean could be stimulated in low RZT.

Krause and associates (2002) suggested that T3SS genes are induced by genistein through NodD1 and NodW in B. japonicum. However, the genome-scale expression analyses indicate that the T3SS gene cluster (EC-III) was fully induced by SSE but not by a single soybean-released isoflavone (genistein or daidzein) or a mixture of both (data not shown). Recently, soluble plant cell signals were reported to induce the expression of the T3SS genes of Pseudomonas syringae (Haapalainen et al. 2009). Although the constituent parts of SSE are complicated, the available whole-sequence information of the $B . j a$ -

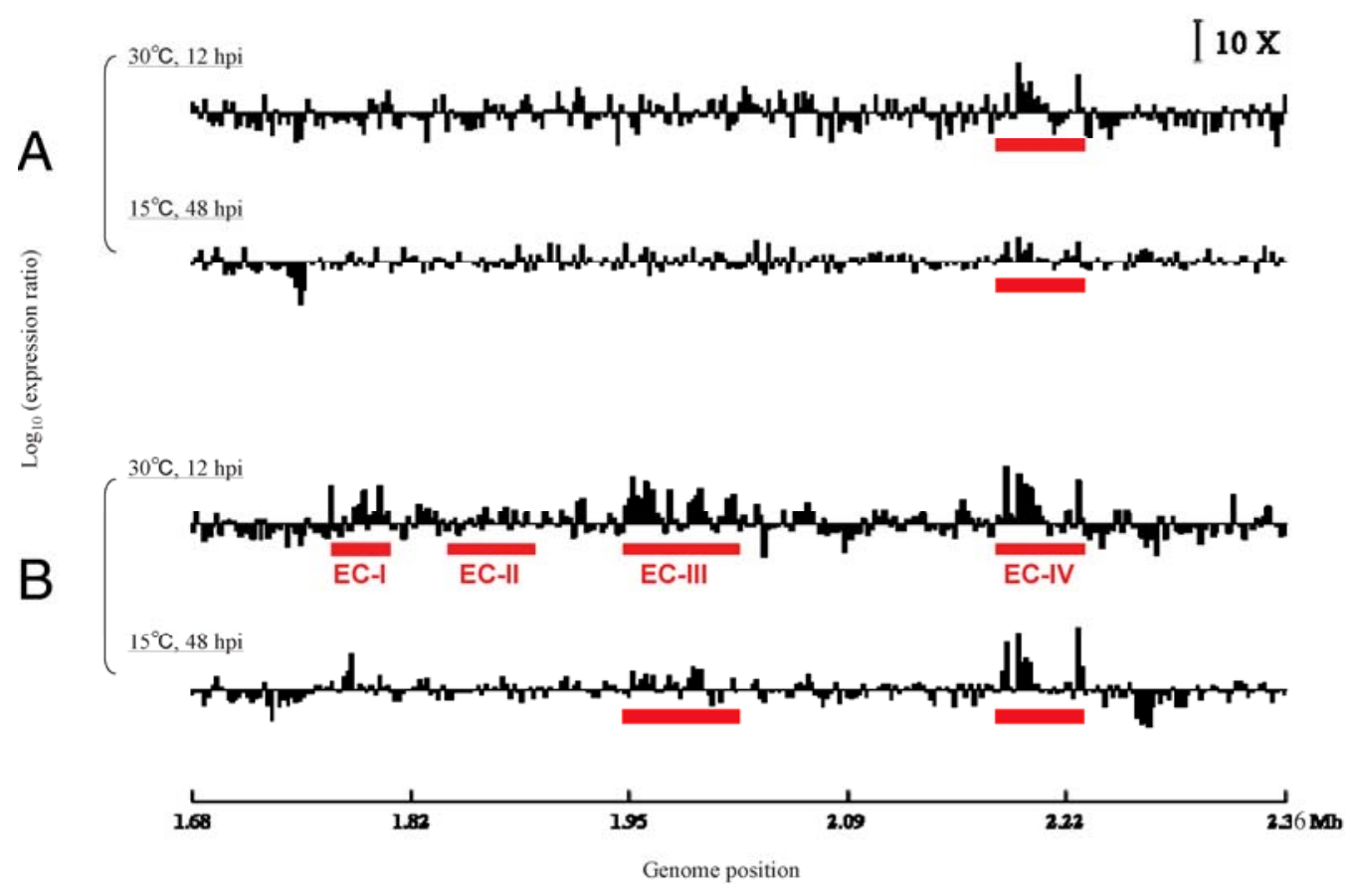

Fig. 6. Expression profiles of symbiosis island in strains $\mathbf{A}, \Delta 370$ and $\mathbf{B}, \mathrm{BjB} 3$ cells in response to soybean seed extract at $30^{\circ} \mathrm{C}, 12 \mathrm{~h}$ postinduction (hpi) and $15^{\circ} \mathrm{C}, 48 \mathrm{hpi}$. The red bars indicate the four predominant expression clusters (EC-I to EC-IV). 
ponicum genome allowed us to gain insights into the regulatory mechanism of the T3SS gene cluster. This led to the finding that both nolA and nodD2 are exclusively co-induced with the T3SS gene cluster by SSE and an assumption that they may be involved in the positive regulation of the T3SS genes expression. Because NolA induces NodD2 expression which, in turn, represses the nod genes induced by genistein via quorum regulation (Loh et al. 2001), we evaluated whether or not the induction of T3SS is quorum activated via NolA-NodD2. Many important pathogenic determinants such as T3SS, EPS, and degradative exoenzymes were reported to be controlled in a cell-density-dependent manner in several plant pathogens as well as enterohemorrhagic and enteropathogenic Escherichia coli (Sperandio et al. 1999; Soto et al. 2006). As expected, the induction of genes encoding conserved parts of T3SS (i.e., tts I and $r h c N$ ) was enhanced with the addition of CM and CDF in the wild-type strain. However, it was completely undetected in strain $\Delta 370$, suggesting that even a weaker induction of nodD2 is required for the T3SS gene expression in genistein-treated wild-type cells. Actually, nodD2 was induced 2.4-fold by genistein at $30^{\circ} \mathrm{C}, 12 \mathrm{hpi}$ and $15^{\circ} \mathrm{C}, 48 \mathrm{hpi}$ (Table 1). The nodD2 was previously shown to be expressed at a very low level in $B$. japonicum after incubation at $30^{\circ} \mathrm{C}$ for approximately 2 weeks (Göttfert et al.1992).

The T3SS gene cluster was fully induced in SSE-treated cells, which showed a significantly rapid growth, and its expression was also activated in cells with high population density. However, it is uncertain whether such stimulated induction occurs through the same pathway between these two cellular statuses due to the lack of experimental evidence that bradyoxetin accumulated in SSE-treated culture. Bradyoxetin is a recently proposed unique quorum signal (autoinducer) accumulated in the culture medium of B. japonicum cells at a high population density (Loh et al. 2002a) but is not currently commercially available. Nevertheless, the finding that gene blr1063, which encodes a putative autoinducer synthase in B. japonicum, was strongly repressed by SSE at both $30^{\circ} \mathrm{C}(12 \mathrm{hpi})$ and $15^{\circ} \mathrm{C}$ (48 hpi) (data not shown), and that the nolA mutation did not result in the elimination of T3SS expression, might imply that the regulatory network of T3SS genes in SSE-treated cells differs from that in cells with high-density populations.

Until now, there have been no reports on the direct interaction between NolANodD2 and T3SS except for recent evidence that all of them maximally expressed at the stage of bacteroids development (Pessi et al. 2007). At present, no clear explanation can be offered as to why the expression of T3SS genes is not substantially influenced in SSE-treated BjB3, although the nolA mutant showed some features similar to those of T3SS mutants (i.e., delayed nodule development and involvement in the host plant genotype-specific dependence) (Sadowsky et al. 1991; Garcia et al. 1996; Krause et al. 2002). The B. japonicum nolA was reported to encode three functionally distinct proteins (Garcia et al. 1996; Loh et al. 1999), suggesting that it may play a more complex functional role in the $B$. japonicum-soybean interaction. Göttfert and associates $(1989,1992)$ reported that $\Delta 370$ showed a clear delay in nodulation but no function could be attributed, thus far, to nodD2 because nodD2 did not promote nodC-lacZ expression with the addition of isoflavones. This suggested that nodD2 was induced by other soybean plant-released compounds and is involved in the induction of unknown genome loci other than the nod genes loci. The present study shows that nodD2 is dramatically induced by SSE but not genistein, and that the elimination of T3SS gene expression in $\Delta 370$ may be one major reason for the delayed nodulation previously observed by Göttfert and associates (1989). Interestingly, compared with the wild type, the expression of clones covering the common nodABCSUIJ operon (in EC-IV) was lower in both mutants, especially in $\Delta 370$, suggesting that the expression of the common nodABCSUIJ operon is affected by the mutation of either nolA or nodD2 (Fig. 6). This suggests the possibility that, in B. japonicum, NodD1NodD2NolA, particularly NodD1NodD2 (stronger and weaker expression of nodD2 in SSE- and genistein-treated cells, respectively), likely functions as a transcriptional unit in the initial interaction with the soybean plant. Recently, a nodD2-containing cosmid clone (at the coordinate $2,169,483$ to $2,194,005$ ) was introduced into the mutant $\Delta 370$ for the functional complementation of NodD2. Unexpectedly, the nodD2 gene as well as the selected T3SS genes (ttsI and $r h c N$ ) were not induced by the SSE (data not shown). As a result, the nodD2-complemented $\Delta 370$ has not yet been obtained. This implies that nodD2 is a tightly regulated gene involved in the intricate network in B. japonicum.

So far, soybean plant-released isoflavones such as genistein have been used to build the inventory of the molecular response of B. japonicum in the early stage of symbiosis. In this experiment, however, SSE was utilized to monitor the global expression profiling of $B$. japonicum at low temperature and provided some new insights into the symbiotic association with T3SS regulation in bacteria. This report shows that SSE is essential for the full induction of B. japonicum T3SS genes, which are potentially delayed at low temperature but positively temperature and cell-density dependent. Additionally, it was shown that nodD2 seems to be required for the induction of T3SS genes. These results suggest that, if the induction of nodD2 gene followed by the expression of T3SS genes is enhanced by the effective methods such as the pretreatment with SSE before sowing or genetic engineering, the nodulation ability of $B$. japonicum cells in soybean could be improved in low RZT area.

\section{MATERIALS AND METHODS}

\section{Bacterial strains and culture conditions.}

B. japonicum USDA 110 is referred to as a wild type. B. japonicum ZB977, a derivative of $B$. japonicum USDA 110 harboring a plasmid (pZB32) which carries a translational nodYlac $Z$ fusion, was described by Banfalvi and associates (1988). Strains $\triangle 370$ (nodD2 deletion mutant) and BjB3 (nolA deletion mutant) were previously described (Göttfert et al. 1989; Garcia et al. 1996). These B. japonicum strains were maintained on the yeast extract-mannitol agar medium (Jordan 1984) supplemented with appropriate antibiotics: chloramphenicol (30 $\mu \mathrm{g} / \mathrm{ml})$, tetracycline $(50 \mu \mathrm{g} / \mathrm{ml})$, kanamycin $(100 \mu \mathrm{g} / \mathrm{ml})$, spectinomycin $(100 \mu \mathrm{g} / \mathrm{ml})$, or streptomycin $(100 \mu \mathrm{g} / \mathrm{ml})$. All strains were grown in the yeast extract-mannitol broth (YMB) supplemented with appropriate antibiotics: chloramphenicol (30 $\mu \mathrm{g} / \mathrm{ml})$, tetracycline $(25 \mu \mathrm{g} / \mathrm{ml})$, kanamycin $(50 \mu \mathrm{g} / \mathrm{ml})$, spectinomycin $(50 \mu \mathrm{g} / \mathrm{ml})$, or streptomycin $(50 \mu \mathrm{g} / \mathrm{ml})$.

\section{$\beta$-Galactosidase activity assay.}

Soybean (G. $\max$ L. Merr. cv. Enrei) seed extract was prepared according to the previous report (Smit et al. 1992) and genistein (4',5,7-trihydroxyisoflavone, from soybean) was purchased from Sigma Corp. (Tokyo). B. japonicum ZB977 cells grown in the $\log$-phase at $30^{\circ} \mathrm{C}$ were diluted to 0.1 of $\mathrm{OD}_{600}$ with fresh $\mathrm{YMB}$ containing no antibiotics and induced with SSE at $20 \mu \mathrm{l} / \mathrm{ml}$ of culture or $5 \mu \mathrm{M}$ genistein for $24 \mathrm{~h}$ at $15^{\circ} \mathrm{C}$. Induction was carried out in $50 \mathrm{ml}$ of YMB and a portion of culture $(2 \mathrm{ml})$ was withdrawn at 3 -h intervals for measuring $\beta$ galactosidase activity as described previously (Banfalvi et al. 1988).

Preparation of conditioned medium and cell density factor.

B. japonicum USDA 110 cells were cultured in $8,500 \mathrm{ml}$ of YMB and grown to 1.6 to 1.8 of $\mathrm{OD}_{600}$ at $30^{\circ} \mathrm{C}$. Then, the cells 
were harvested by centrifugation $(13,000 \times g)$ and one-half of the supernatant was concentrated 42.5 -fold by rotary evaporation and used as CM for induction assays (Loh et al. 2002b). Another half was concentrated 85-fold and extracted with ethyl acetate $(1: 1 \mathrm{vol} / \mathrm{vol})$. After the ethyl acetate layer was dried by rotary evaporation, the residues were dissolved in $50 \%$ ethanol and used as CDF as described previously (Loh et al. 2002a). To avoid the influence of high salts caused by the concentration process on gene expression, $24 \mu \mathrm{l}$ of CM and 12 $\mu \mathrm{l}$ of CDF per milliliter of the induction medium were used.

\section{RNA isolation, cDNA synthesis and macroarray analyses.}

For the RNA isolation, cells were precultured in $20 \mathrm{ml}$ of YMB with antibiotics described above for 3 days and scaled up to $200 \mathrm{ml}$ of YMB without antibiotics for growing to logphase $\left(\mathrm{OD}_{600}=0.3\right.$ to 0.5$)$ at $30^{\circ} \mathrm{C}$. Then, the cells were diluted with fresh YMB to 0.1 of $\mathrm{OD}_{600}$ for the induction with SSE $(20 \mu \mathrm{l} / \mathrm{ml}$ of culture $)$ and genistein $(5 \mu \mathrm{M})$ at 30 or $15^{\circ} \mathrm{C}$. RNA isolation, hybridization, image capture, and data analyses were performed as described previously (Wei et al. 2008). Briefly, after the equal volume of ice-cold 5\% (wt/vol) phenol/ ethanol was added into the culture to minimize the degradation of RNA (Inaba et al. 2003), total RNA was isolated with ISOGEN-LS (Nippon Gene, Tokyo) and then treated with DNase I. After the removal of rRNA with the MICROBExpress Kit (Ambion, Austin, TX, U.S.A.), the first-strand [ $\alpha$ $\left.{ }^{33} \mathrm{P}\right] \mathrm{dCTP}$-incorporated cDNAs were synthesized by random priming using SuperScript II Reverse Transcriptase (Invitrogen, Carlsbad, CA, U.S.A.) according to the manufacturer's instructions. The labeled cDNAs were purified through AutoSeq G-50 (GE Healthcare Bio-Sciences, Piscataway, NJ, U.S.A.) and hybridized with DNA array sheets at $55^{\circ} \mathrm{C}$ overnight. Hybridized signals were captured by using a BioImaging analyzer (BAS 5000; Fuji Film, Tokyo). The signal intensity of each spot was quantified by using ArrayVision software (GE Healthcare Bio-Sciences) and normalized on the basis of the total sum of the signal intensities of spots on the array membrane. The data analysis was done as described previously (Wei et al. 2008). Duplicate array membranes were used in each experiment and at least two independent experiments were examined.

\section{Quantitative real-time reverse-transcriptase PCR.}

Total RNA isolation was performed as described above and the primers were designed by Primer 3 (Rozen and Skaletsky 2000). Oligonucleotides of the primers for genes nodW, ttsI, $r h c N$, blr1649, and sigA were described previously (Wei et al. 2008). Primers for the amplification of other genes were nodD2 (forward): CTAATAACTGAGCGCAACCT, nodD2 (reverse): TGAGCTCAAGACAAGTTCG, nolA (forward): CTGAAGGTACTTGCACGATT, and nolA (reverse): AGTAA GGCTGATCCTCCAAT. Total RNA (100 to $300 \mathrm{ng}$ ) was used as template and real-time reverse-transcriptase (RT)-PCR reactions were performed with MiniOpticon (version 3.1; Bio-Rad, Hercules, CA, U.S.A.) in combination with the QuantiTect SYBR Green RT-PCR (Qiagen GmbH, Hilden, Germany). Quantification was performed using the Pfaffl method according to the real time RT-PCR application guide provided by Bio-Rad. A housekeeping gene of B. japonicum, sigA, which showed no significant change in expression level under the growth conditions in this experiment, was used as an internal reference.

\section{ACKNOWLEDGMENTS}

This work was supported in part by the 21st Century Center of Excellence (COE) Program, Iwate University, Japan. We thank G. Stacey of the
University of Missouri, Columbia, in the United States for providing us with strains $\Delta 370$ and $\mathrm{BjB} 3$.

\section{LITERATURE CITED}

Banfalvi, Z., Nieuwkoop, A., Schell, M. G., Besl, L., and Stacey, G. 1988. Regulation of nod gene expression in Bradyrhizobium japonicum. Mol. Gen. Genet. 214:420-424.

Becker, B. U., Kosch, K., Parniske, M., and Müller, P. 1998. Exopolysaccharide (EPS) synthesis in Bradyrhizobium japonicum: Sequence, operon structure and mutational analysis of an exo gene cluster. Mol. Gen. Genet. 259:161-171.

Belkheir, A. M., Zhou, X., and Smith, D. L. 2000. Response of soybean (Glycine max (L.) Merr.) cultivars to genistein-preincubated Bradyrhizobium japonicum: Nodulation and dry matter accumulation under Canadian short-season conditions. J. Agron. Crop Sci.185:167-175.

Broughton, W. J., Jabbouri, S., and Perret, X. 2000. Keys to symbiotic harmony. J. Bacteriol. 182:5641-5642.

Dart, P., and Day, J. 1971. Effects of incubation temperature and oxygen tension on nitrogenase activity of legume root nodules. Plant Soil 35:167-184.

Duzan, H. M., Mabood, F., Souleimanov, A., and Smith, D. L. 2006. Nod $\mathrm{Bj}-\mathrm{V}\left(\mathrm{C}_{18: 1}\right.$, MeFuc) production by Bradyrhizobium japonicum (USDA110, 532C) at suboptimal growth temperatures. J. Plant. Physiol. 163:107-111.

Garcia, M., Dunlap, J., Loh, J., and Stacey, G. 1996. Phenotypic characterization and regulation of nolA gene of Bradyrhizobium japonicum. Mol. Plant-Microbe Interact. 9:625-635.

Göttfert, M., Lamb, J.W., Gasser, R., Semenza, J., and Hennecke, H. 1989. Mutational analysis of the Bradyrhizobium japonicum common nod genes and further nod box-linked genomic DNA regions. Mol. Gen. Genet. 215:407-415.

Göttfert, M., Holzhäuser, D., Bäni, D., and Hennecke, H. 1992. Structural and functional analysis of two different nodD genes in Bradyrhizobium japonicum USDA 110. Mol. Plant-Microbe Interact. 5:257-265.

Göttfert, M., Röthlisberger, S., Kündig, C., Beck, C., Marty, R., and Hennecke, H. 2001. Potential symbiosis-specific genes uncovered by sequencing a 410-kilobase DNA region of the Bradyrhizobium japonicum chromosome. J. Bacteriol. 183:1405-1412.

Haapalainen, M., Gestel, K., Pirhonen, M., and Taira, S. 2009, Soluble plant cell signals induction the expression of the type III secretion system of Pseudomonas syringae and upregulate the production of pilus protein HrpA. Mol. Plant-Microbe Interact. 22:282-290.

Inaba, M., Suzuki, I., Szalontai, B., Kanesaki, Y., Los, D. A., Hayashi, H., and Murata, N. 2003. Gene-engineered rigidification of membrane lipids enhances the cold inducibility of gene expression in synechocystis. J. Biol. Chem. 278:12191-12198.

Jitacksorn, S., and Sadowsky, M. J. 2008. Nodulation gene regulation and quorum sensing control density-dependent suppression and restriction of nodulation in the Bradyrhizobium japonicum-soybean symbiosis. Appl. Environ. Microbiol. 74:3749-3756.

Jones, F. R., and Tisdale, W. B. 1921. Effect of soil temperature upon the development of nodules on the roots of certain legumes. J. Agric. Res. (Cambridge). 22:17-37.

Jordan, D. C. 1984. Pages 234-244 in: Bergey's Manual of Systematic Bacteriology, Vol. 1. N. R. Krieg, and J. G. Holt, eds. Williams \& Wilkins, London.

Kaneko, T., Nakamura, Y., Sato, S., Minamisawa, K., Uchiumi, T., Sasamoto, S., Watanabe, A., Idesawa, K., Iriguchi, M., Kawashima, K., Kohara, M., Matsumoto, M., Shimpo, S., Tsuruoka, H., Wada, T., Yamada, M., and Tabata, S. 2002. Complete genomic sequence of nitrogen-fixing symbiotic bacterium Bradyrhizobium japonicum USDA 110. DNA Res. 9:189-197.

Kosslak, R. M., Bookland, R., Barkei, J., Paaren, H. E., and Appelbaum, E. R. 1987. Induction of Bradyrhizobium japonicum common nod genes by isoflavones isolated from Glycine max. Proc. Natl. Acad. Sci. U.S.A. 84:7428-7432.

Krause, A., Doerfel, A., and Göttfert, M. 2002. Mutational and transcriptional analysis of the type III secretion system of Bradyrhizobium japonicum. Mol. Plant-Microbe Interact. 15:1228-1235.

Lang, K., Lindemann, A., Hauser, F., and Göttfert, M. 2008. The genistein stimulon of Bradyrhizobium japonicum. Mol. Gen. Genet. 279:203-211.

Leibovitch, S., Migner, P., Zhang, F., and Smith, D. L. 2001. Evaluation of the effect of soyasignal technology on soybean yield (Glycine $\max (\mathrm{L}$.) Merr.) under field conditions over 6 years in eastern Canada and northern United States. J. Agron. Crop Sci. 187:281292. 
Loh, J., and Stacey, G. 2003. Nodulation gene regulation in Bradyrhizobium japonicum: A unique integration of global regulatory circuits. Appl. Environ. Microbiol. 69:10-17.

Loh, J., Stacey, M. G., Sadowsky, M. J., and Stacey, G. 1999. The Bradyrhizobium japonicum nolA gene encodes three functionally distinct proteins. J. Bacteriol. 181:1544-1554.

Loh, J., Yuen-Tsai, J. P. Y., Stacey, M. G., Lohar, D., Welborn, A., and Stacey, G. 2001. Population density-dependent regulation of the Bradyrhizobium japonicum nodulation genes. Mol. Microbiol. 42:37-46.

Loh, J., Carlson, R. W., York, W. S., and Stacey, G. 2002a. Bradyoxetin, a unique chemical signal involved in symbiotic gene regulation. Proc. Natl. Acad. Sci. U.S.A. 99:14446-14451.

Loh, J., Lohar, D., Andersen, B., and Stacey, G. 2002b. A two-component regulator mediates population density dependent expression of the $\mathrm{Bra}$ dyrhizobium japonicum nodulation genes. J. Bacteriol. 184:1759-1766.

Lynch, D. H., and Smith, D. L. 1993. Soybean (Glycine max) nodulation and $\mathrm{N}_{2}$-fixation as affected by exposure to a low-zone temperature. Physiol. Plant. 88:212-220.

Olsthoorn, M., Stokvis, E., Haverkamp, J., Spaink, H. P., and ThomasOates, J. 2000. Growth temperature regulation of host-specific modifications of rhizobial lipo-chitin oligosaccharides: The function of nodX is temperature regulated. Mol. Plant-Microbe Interact. 13:808820

Pessi, G., Ahrens, C. H., Rehrauer, H., Lindeman, A., Hauser, F., Fischer, H. M., and Hennecke, H. 2007. Genome-wide transcript analysis of Bradyrhizobium japonicum bacteroids in soybean root nodules. Mol. Plant-Microbe Interact. 20:1353-1363.

Rozen, S., and Skaletsky, H. J. 2000. Pages 365-386 in: Bioinformatics Methods and Protocols: Primer3 on the WWW for General Users and for Biologist Programmers. S. Krawetz and S. Misener, eds. Humana Press, Totowa, NY, U.S.A.

Sadowsky, M. J., Cregan, P. B., Göttfert, M., Sharma, A., Gerhold, D., Rodriguez-Quiñones, F., Keyser, H. H., Hennecke, H., and Stacey, G. 1991. The Bradyrhizobium japonicum nolA gene and its involvement in the genotype-specific nodulation of soybeans. Proc. Natl. Acad. Sci. U.S.A. 88:637-641.

Schultze. M., and Kondorosi. A. 1998. Regulation of symbiotic root nodule development. Annu. Rev. Genet. 32:33-57.

Smit, G., Puvanesarajah, V., Carlson, R.W., Barbour, W. M., and Stacey, G. 1992. Bradyrhizobium japonicum nodD1 can be specifically induced by soybean flavonoids that do not induce the nodYABCSUIJ operon. J. Biol. Chem. 267:310-318.

Soto, M. J., Sanjuan, J., and Olivares, J. 2006. Rhizobia and plant-pathogenic bacteria: Common infection weapons. Microbiology 152:31673174.

Sperandio, V., Mellies, J. L., Nguyen, W., Shin, S., and Kaper, J. B. 1999.
Quorum sensing controls expression of the type III secretion gene transcription and protein secretion in enterohemorrhagic and enteropathogenic Escherichia coli. Proc. Natl. Acad. Sci. U.S.A. 96:1519615201.

Süß, C., Hempel, J., Zehner, S., Krause, A., Patschkowski, T., and Göttfert, M. 2006. Identification of genistein-inducible and type III-secreted proteins of Bradyrhizobium japonicum. J. Biotechnol. 126:69-77.

Valls, M., Genin, S., and Boucher, C. 2006. Integrated regulation of the type III secretion system and other virulence determinants in Ralstonia solanacearum. PLoS Pathogens., Vol. 2, No. 8, e82 doi:10.1371/journal.ppat.0020082.

Wei, M., Yokoyama, T., Minamisawa, K., Mitsui, H., Itakura, M., Kaneko, T., Tabata, S., Saeki, K., Omori, H., Tajima, S., Uchiumi, T., Abe, M., and Ohwada, T. 2008. Soybean seed extracts preferentially express genomic loci of Bradyrhizobium japonicum in the initial interaction with soybean, Glycine $\max (\mathrm{L}$.) Merr. DNA Res. 15:201-214.

Zahram, H. H. 1999. Rhizobium-legume symbiosis and nitrogen fixation under severe conditions and in an arid climate. Microbiol. Mol. Biol. Rev. 63:968-989.

Zehner, S., Schober, G., Wenzel, M., Lang, K and Göttfert, M. 2008. Expression of Bradyrhizobium japonicum type III secretion system in legume nodules and analysis of the associated tts box promoter. Mol. Plant-Microbe Interact. 21:1087-1093.

Zhang, F., and Smith, D. L. 1994. Effects of low root zone temperatures on the early stages of symbiosis establishment between soybean (Glycine max (L.) Merr.) and Bradyrhizobium japonicum. J. Exp. Bot. 45:1467-1473.

Zhang, F., and Smith, D. L. 1996. Genistein accumulation in soybean (Glycine $\max (\mathrm{L}$.$) Merr.) root systems under suboptimal root zone$ temperatures. J. Exp. Bot. 47:785-792.

Zhang, F., and Smith, D. L. 1997. Application of genistein to inocula and soil to overcome low spring soil temperature inhibition of soybean nodulation and nitrogen fixation. Plant Soil 192:141-151.

Zhang, H., Prithiviraj, B., Souleimanov, A., D'Aoust, F., Charles, T. C., Driscoll, B. T., and Smith, D. L. 2002. The effect of temperature and genistein concentration on lipo-chitooligosaccharide (LCO) production by wild-type and mutants of Bradyrhizobium japonicum. Soil Biol. Biochem. 34:1175-1180.

\section{AUTHOR-RECOMMENDED INTERNET RESOURCES}

RhizoBase database (Bradyrhizobium japonicum) genome.kazusa.or.jp/rhizobase/Bradyrhizobium

Osaka University Biology Department Bradyrhizobium japonicum MacroArray analysis: orca10.bio.sci.osaka-u.ac.jp/array02 